\title{
Microstructure and Interfacial Reactions During Vacuum Brazing of Stainless Steel to Titanium Using Ag-28 pct Cu Alloy
}

\begin{abstract}
A. LAIK, A.A. SHIRZADI, G. SHARMA, R. TEWARI, T. JAYAKUMAR, and G.K. DEY
Microstructural evolution and interfacial reactions during vacuum brazing of grade- $2 \mathrm{Ti}$ and 304L-type stainless steel (SS) using eutectic alloy Ag-28 wt pct $\mathrm{Cu}$ were investigated. A thin $\mathrm{Ni}$-depleted zone of $\alpha-\mathrm{Fe}(\mathrm{Cr}, \mathrm{Ni})$ solid solution formed on the SS-side of the braze zone (BZ). $\mathrm{Cu}$ from the braze alloy, in combination with the dissolved Fe and Ti from the base materials, formed a layer of ternary compound $\tau_{2}$, adjacent to $\mathrm{Ti}$ in the BZ. In addition, four binary intermetallic compounds, $\mathrm{Cu}_{3} \mathrm{Ti}_{2}, \mathrm{Cu}_{4} \mathrm{Ti}_{3}, \mathrm{CuTi}$ and $\mathrm{CuTi}_{2}$ formed as parallel contiguous layers in the BZ. The unreacted $\mathrm{Ag}$ solidified as islands within the layers of $\mathrm{Cu}_{3} \mathrm{Ti}_{2}$ and $\mathrm{Cu}_{4} \mathrm{Ti}_{3}$. Formation of an amorphous phase at certain locations in the BZ could be revealed. The $\beta$ - Ti $(\mathrm{Cu})$ layer, formed due to diffusion of $\mathrm{Cu}$ into Ti-based material, transformed to an $\alpha$-Ti + $\mathrm{CuTi}_{2}$ eutectoid with lamellar morphology. Tensile test showed that the brazed joints had strength of $112 \mathrm{MPa}$ and failed at the $\mathrm{BZ}$. The possible sequence of events that led to the final microstructure and the mode of failure of these joints were delineated.
\end{abstract}

DOI: $10.1007 / \mathrm{s} 11661-014-2671-9$

(C) The Minerals, Metals \& Materials Society and ASM International 2014

\section{INTRODUCTION}

TITANIUM and its alloys find applications in various sectors such as aerospace, chemical, biomedical, and nuclear due to their high strength to weight ratio and corrosion resistance properties. ${ }^{[1,2]}$ The range of application of these materials, in combination with other structural materials, such as stainless steels (SS), is greatly enhanced by the appropriate selection of joining techniques. Dissimilar materials joints between stainless steel and titanium are widely used in the aerospace engineering, heat exchangers in chemical and petrochemical industries, sub-assemblies in nuclear reactors, and nuclear fuel reprocessing plants, particularly in the dissolver assembly for reprocessing of spent nuclear fuel. ${ }^{[3-7]}$ Brazing is widely employed in joining dissimilar materials. ${ }^{[8,9]}$ The choice of vacuum brazing for joining $\mathrm{Ti}$ alloys and stainless steels, in preference to fusion welding, diffusion bonding, and explosion welding, is elaborated elsewhere. ${ }^{[10]}$

Silver-based alloys are very often used for joining Ti and its alloys, primarily due to their good wetting characteristics and high strength coupled with adequate ductility in the brazed joints. ${ }^{[]}$Given its importance in engineering applications, the brazing of $\mathrm{Ti}$ and its alloys with steels has been investigated quite extensively.

A. LAIK, Scientific Officer (F), R. TEWARI, Scientific Officer $(\mathrm{H})$, and G.K. DEY, Associate Director, are with the Materials Science Division, Bhabha Atomic Research Centre, Mumbai 400 085, India. Contact e-mail: laik@barc.gov.in A.A. SHIRZADI, Lecturer, is with the Materials Engineering, The Open University, Milton Keynes MK7 6AA, U.K. G. SHARMA, Scientific Officer (G), is with the Mechanical Metallurgy Division, Bhabha Atomic Research Centre. T. JAYAKUMAR, Director, is with the Metallurgy and Materials Group, Indira Gandhi Centre for Atomic Research, Kalpakkam 603 102, Tamil Nadu, India.

Manuscript submitted June 18, 2014.

Article published online November 27, 2014
Nevertheless, the objective of these earlier studies circled around the suitability of the use of various brazing alloys and optimizing the parameters with respect to mechanical properties. ${ }^{[1-18]}$ The development of a suitable brazing technique essentially incorporates an in-depth understanding of the interfacial chemical reactions and identifying the mechanisms of these reactions, which can be used to optimize the bonding conditions, and hence achieve desirable properties of the joints. Recently, Shiue et al. ${ }^{[19]}$ have demonstrated the formation of layers of intermetallic compounds during reactive wetting of $\mathrm{Ag}-28 \mathrm{Cu}$ braze alloy with $\mathrm{Ti}$ substrate. Formation of such layered microstructure, during the brazing of stainless steel to titanium using $\mathrm{Ag}-\mathrm{Cu}$ alloys in the temperature range of $1075 \mathrm{~K}$ to $1223 \mathrm{~K}\left(800{ }^{\circ} \mathrm{C}\right.$ to $950{ }^{\circ} \mathrm{C}$ ), was reported by Shafiei et al. ${ }^{[20]}$ Similar investigations on brazing of $\mathrm{Ti}$ and steel using $\mathrm{Ag}-\mathrm{Cu}-$ based alloys were also reported by Yue et al. ${ }^{[12]}$ and Elrefaey and Tillmann. ${ }^{[13]}$ However, there is considerable disagreement regarding the formation of various intermetallic phases by the interfacial reactions in these reports. ${ }^{[20]}$ Thus, a clear understanding of the mechanisms of these reactions and formation of the resultant products has not emerged from the earlier studies.

The objective of the present work, therefore, is to carry out an in-depth investigation on the microstructural evolution and phase relationship during brazing of stainless steel to titanium using $\mathrm{Ag}$-28 wt pct $\mathrm{Cu}$ eutectic alloy. The mechanisms of the interfacial reactions have also been identified in this work.

\section{EXPERIMENTAL PROCEDURE}

Cylindrical rods of $14 \mathrm{~mm}$ diameter and $35 \mathrm{~mm}$ height of austenitic stainless steel (AISI 304L) and grade-2 titanium (ASTM B265) were brazed together using $50-\mu \mathrm{m}$ 
thick foils of $\mathrm{Ag}-28$ wt pet $\mathrm{Cu}$ alloy $(\mathrm{Ag}-28 \mathrm{Cu})$, commercially known as Cusil, * with eutectic temperature of $1053 \mathrm{~K}$

*Cusil is a trademark of Wesgo Metals, a part of The Morgan Advanced Materials Plc., Berkshire SL4 1LP, UK.

$\left(780{ }^{\circ} \mathrm{C}\right)$. The nominal compositions of the base materials are given in Table I. Prior to brazing, the joining faces of the rods were ground with successive grades of emery paper up to 1200 grit, and all the components were cleaned in an ultrasonic bath containing acetone.

The Ti and SS pieces were clamped together with Ag$28 \mathrm{Cu}$ alloy foil, in an induction heating vacuum brazing furnace, with a load of $10 \mathrm{~kg}$ to keep them in place. The furnace was maintained at about $5 \times 10^{-5}$ mbar vacuum and the temperature of the sample was monitored with a thermocouple spot welded on the body of the Ti piece, close to the SS-Ti interface. The assembly was heated to the peak brazing temperature of $1108 \mathrm{~K}\left(835^{\circ} \mathrm{C}\right)$, at the rate of $0.833 \mathrm{~K} / \mathrm{s}\left(50^{\circ} \mathrm{C} / \mathrm{min}\right)$, where it was held for 600 seconds, to obtain sufficient wetting of the brazing surfaces and adequate reaction at the interfaces.

Specimens from the cross-section of the joint were prepared using standard metallographic techniques and were subsequently etched with a solution of 5 pct HF, 40 pct $\mathrm{HNO}_{3}$ and 55 pct $\mathrm{H}_{2} \mathrm{O}$, by volume. The microstructure of the braze zone (BZ) was characterized using an optical microscope, and a scanning electron microscope (SEM) equipped with an energy-dispersive spectrometer (EDS). The micro-chemical analysis of the reaction products formed at the interfaces was carried out using a Cameca SX100 electron probe microanalyzer (EPMA) equipped with three wavelength-dispersive spectrometers (WDS). The interfacial microstructure was also characterized at submicron scale using a transmission electron microscope (TEM). The details of specimen preparation is given elsewhere. ${ }^{[10]}$ The variation in hardness across the brazed cross-section was recorded using an ultra-nanohardness tester (UNHT). The maximum load used in the indentations was $3 \mathrm{mN}$ with loading and unloading rate of $0.1 \mathrm{mN} / \mathrm{s}$. The bond strength of the joints was determined using a universal testing machine, using a cross head speed of $1.66 \mu \mathrm{m} / \mathrm{s}$. Xray diffraction (XRD) of the fractured surfaces was carried out using $\mathrm{Cu}-\mathrm{K} \alpha$ radiation in a $\mathrm{X}$-ray diffraction machine.

\section{RESULTS}

\section{A. Microstructure of the Braze Zone}

Figure 1 shows the microstructure of the cross-section of the BZ of the SS-Ti joint using backscattered electron
(BSE) imaging. The entire BZ was found to consist of contiguous layers of various phases, parallel to the interface, marked 1 through 8 in Figure 1. The X-ray maps of the elements $\mathrm{Fe}, \mathrm{Ni}, \mathrm{Cr}, \mathrm{Ag}, \mathrm{Cu}$, and $\mathrm{Ti}$, of the corresponding region, acquired using WDS, are shown in Figure 2. The distribution of the various elements as shown in these X-ray maps clearly depicts the partitioning behavior and interplay of the elements in the BZ. The chemical compositions of the various phases formed in the BZ, marked as 1 through 8 in Figure 1 are listed in Table II.

On the SS-side of the BZ, just adjacent to the base material, a $2-\mu \mathrm{m}$ thick continuous layer, labeled as 1 in Figure 1, was found to form parallel to the original interface due to interaction of the brazing alloy with SS. The composition of the layer, as can be seen in Table II, has been altered to some extent from that of SS-304L. $\mathrm{Ni}$ content in the layer got reduced from about 7 at. pct in the base material to 2.1 at. pet with a simultaneous enrichment of $\mathrm{Cr}$ from 20 at. pct up to 24.2 at. pct. Also, the layer got enriched in $\mathrm{Cu}$ and $\mathrm{Ti}$, concentrations being 4.7 and 3.8 at. pct, respectively, due to diffusion of these elements from the braze-melt. Therefore, based on the composition, it was assumed that the layer 1 consisted of $\alpha-\mathrm{Fe}(\mathrm{Cr}, \mathrm{Ni})$ solid solution, the formation of which was facilitated by dissolution of $\mathrm{Ni}$ in the Ag- $\mathrm{Cu}$ braze alloy melt and simultaneous inward diffusion of $\mathrm{Ti}$ and $\mathrm{Cu}$ to the SS substrate, due to solidliquid interaction. Some pockets of unreacted residual $\mathrm{Ag}$ were also seen in form of isolated bright regions

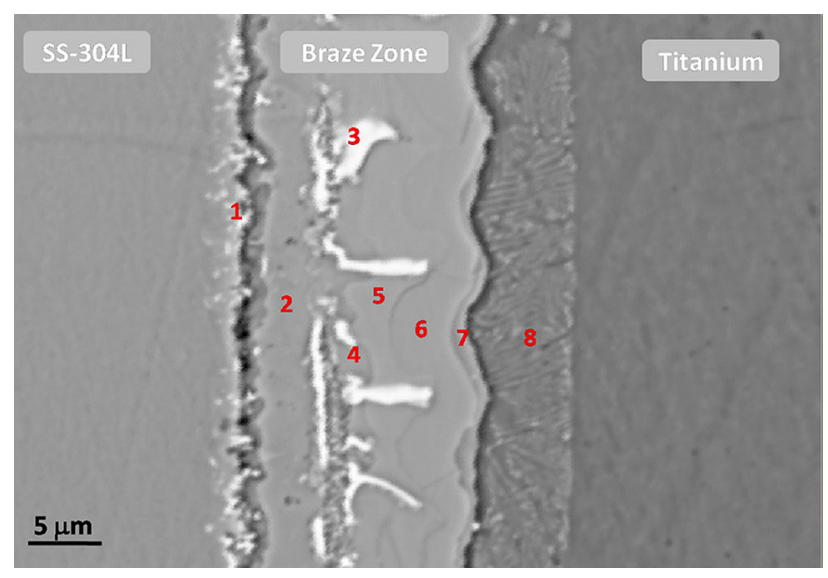

Fig. 1-Backscattered electron image of the cross-section of SS-Ti joint brazed with $\mathrm{Ag}-28$ wt pet $\mathrm{Cu}$ alloy at $1108 \mathrm{~K}\left(835^{\circ} \mathrm{C}\right)$ for 10 minutes. The compositions of the various phases formed in the braze zone, marked 1 through 8 , are given in Table II.

Table I. Chemical Composition of the Base Materials, in wt pct

\begin{tabular}{llllllllll}
\hline Elements & $\mathrm{C}$ & $\mathrm{H}$ & $\mathrm{O}$ & $\mathrm{Mn}$ & $\mathrm{Si}$ & $\mathrm{Ni}$ & $\mathrm{Cr}$ & $\mathrm{Fe}$ & $\mathrm{Ti}$ \\
\hline Ti Gr-2 & 0.009 & 0.008 & 0.12 & - & - & 0.011 & - & 0.09 & bal. \\
& $(0.036)$ & $(0.38)$ & $(0.358)$ & & & $(0.009)$ & & $(0.076)$ & bal. \\
SS-304L & 0.02 & - & - & 1.47 & 0.52 & 10.6 & 19.1 & - \\
& $(0.09)$ & & & $(1.47)$ & $(1.02)$ & $(9.95)$ & $(20.24)$ & & \\
\hline
\end{tabular}

The values in parentheses are in at. pct. 

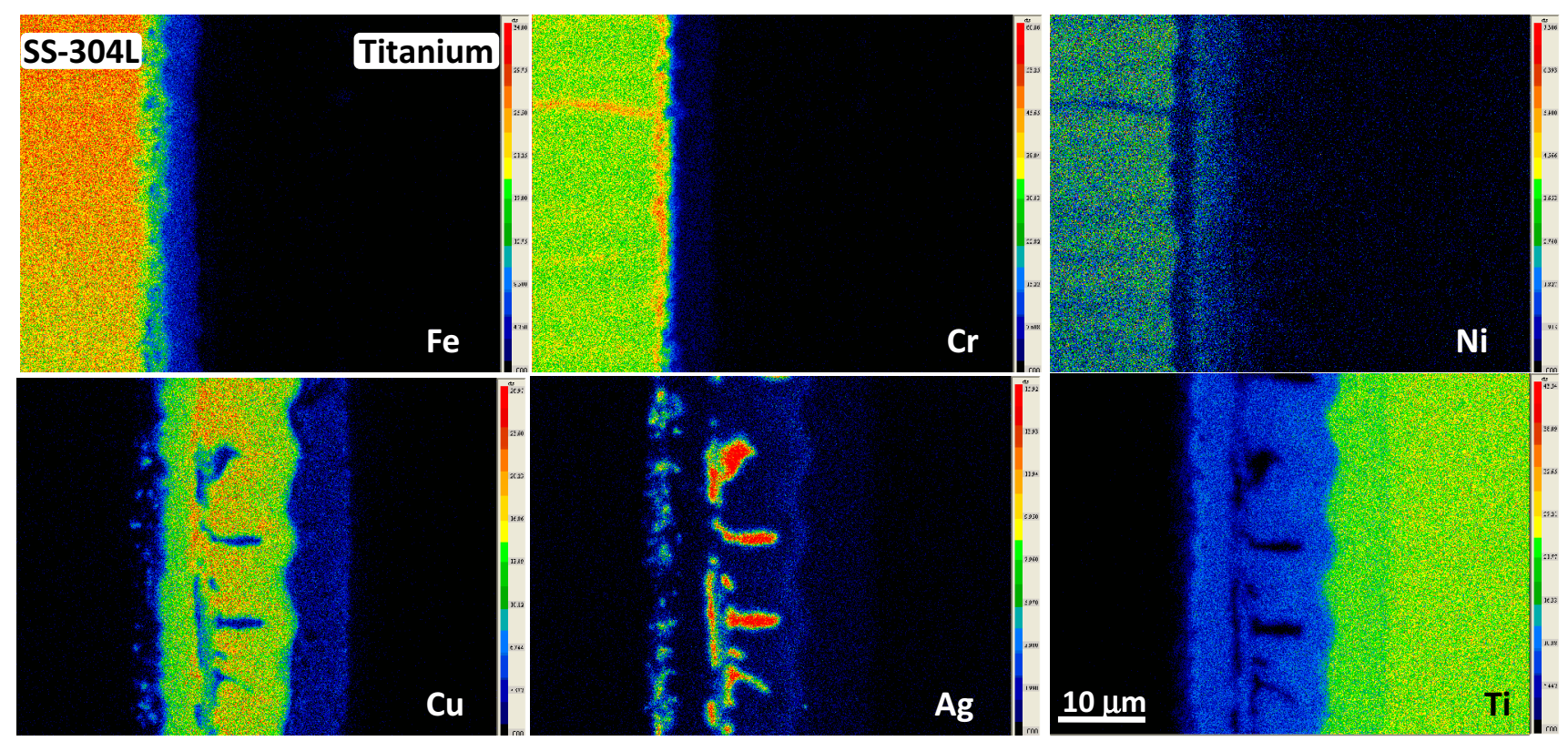

Fig. 2-X-ray maps of $\mathrm{Fe}, \mathrm{Cr}, \mathrm{Ni}, \mathrm{Cu}, \mathrm{Ag}$, and $\mathrm{Ti}$ of a region at the $\mathrm{SS}-\mathrm{Ti}$ joint interface showing the distribution and variation in the relative concentrations of these element in the braze zone.

Table II. Chemical Composition (in at. pct) of the Phases Marked 1 to 8 in Figure 1

\begin{tabular}{lrrrrrrr}
\hline Phase Identity & \multicolumn{1}{c}{$\mathrm{Ti}$} & $\mathrm{Cu}$ & $\mathrm{Ag}$ & $\mathrm{Fe}$ & $\mathrm{Ni}$ & $\mathrm{Cr}$ & Probable Phase \\
\hline 1 & 3.8 & 4.7 & 0.5 & 64.7 & 2.1 & 24.2 & $\alpha-\mathrm{Fe}(\mathrm{Cr}, \mathrm{Ni})$ \\
2 & 39.1 & 46.7 & 0.7 & 9.5 & 3.4 & 0.6 & $\tau_{2}$ \\
3 & 4.2 & 9.4 & 85.9 & 0.2 & 0.2 & 0.1 & $\mathrm{Ag}(\mathrm{Cu}, \mathrm{Ti})$ \\
4 & 35.2 & 60.1 & 3.2 & 1.2 & 0.1 & 0.2 & $\mathrm{Cu}_{3} \mathrm{Ti}_{2}$ \\
5 & 39.8 & 57.7 & 2.2 & 0.1 & 0.2 & 0.0 & $\mathrm{Cu}_{4} \mathrm{Ti}_{3}$ \\
6 & 47.2 & 50.2 & 2.4 & 0.1 & 0.1 & 0.0 & $\mathrm{CuTi}^{2}$ \\
7 & 65.3 & 33.1 & 1.4 & 0.1 & 0.1 & 0.0 & $\mathrm{CuTi}_{2}$ \\
8 & 91.4 & 7.4 & 0.9 & 0.1 & 0.2 & 0.0 & $\alpha-\mathrm{Ti}^{+}+\mathrm{CuTi}_{2}$ \\
\hline
\end{tabular}

decorating layer 1. The presence of $\mathrm{Ag}$ is evidently depicted in the X-ray map of $\mathrm{Ag} \mathrm{L} \alpha$ as shown in Figure 2.

Adjacent to layer 1, a phase marked as 2 in Figure 1, formed as a continuous layer with thickness varying between 2 and $4 \mu \mathrm{m}$, parallel to the interface. As can be seen in Table II, the phase primarily contained $\mathrm{Cu}, \mathrm{Ti}$, $\mathrm{Fe}$, and $\mathrm{Ni}$, with minor concentrations of $\mathrm{Ag}$ and $\mathrm{Cr}$. Figure 3 shows a high-resolution TEM image along with the corresponding SADP and EDS spectrum from this layer. The chemical composition of this layer, determined by EDS analysis in TEM, was in agreement with that of the WDS analysis in EPMA. The SADP could be indexed to the ternary phase, $\tau_{2}$, with composition $\mathrm{Ti}_{40} \mathrm{Cu}_{57-x} \mathrm{Fe}_{x}(x=5$ to 17$)$.

In the BZ, between the layers 2 and 8 , four layers of $\mathrm{Cu}$-Ti intermetallic compounds, labeled as 4, 5, 6, and 7 in Figure 1 were found to form. These layers were identified as $\mathrm{Cu}_{3} \mathrm{Ti}_{2}, \mathrm{Cu}_{4} \mathrm{Ti}_{3}, \mathrm{CuTi}$, and $\mathrm{CuTi}_{2}$, respectively. The thicknesses of the $\mathrm{Cu}_{3} \mathrm{Ti}_{2}, \mathrm{Cu}_{4} \mathrm{Ti}_{3}, \mathrm{CuTi}$ phase layers were not uniform and varied from one point to the other. However, $\mathrm{CuTi}_{2}$ formed as a uniform thin layer of about $0.5 \mu \mathrm{m}$ width. Additionally, a Agrich bright phase, labeled as 3 in Figure 1, formed as isolated islands within the domain of phase layers 4 $\left(\mathrm{Cu}_{3} \mathrm{Ti}_{2}\right)$ and $5\left(\mathrm{Cu}_{4} \mathrm{Ti}_{3}\right)$. Figure 4 shows the bright-field (BF) TEM micrograph along with a high-resolution TEM image and the EDS spectrum acquired from this phase in the BZ. The chemical composition in Table II showed that it contained about 9.4 at. pet $\mathrm{Cu}$ and 4.2 at. pct Ti along with Ag, and hence was considered to be the residual $\operatorname{Ag}(\mathrm{Cu}, \mathrm{Ti})$ solid-solution phase that remained unreacted during the process of brazing and subsequent cooling to room temperature.

Figure 5 shows the bright-field TEM image, the corresponding SADP and electron diffraction ring pattern from the layer 4. The SADP in Figure 5(b) was indexed to the [010] zone axis of the $\mathrm{Cu}_{3} \mathrm{Ti}_{2}$ phase, which has primitive tetragonal structure with $\mathrm{P} 4 / \mathrm{nmm}$ space group. The grain size showed a large range of variation from about a few microns to those below 100 $\mathrm{nm}$ (marked by arrows in Figure 5(a)). It is thus interesting to note the tendency of formation of ring pattern, marked by the presence of faint ring around the central bright spot in Figure 5(b), due to the presence of nanocrystalline grains in the $\mathrm{Cu}_{3} \mathrm{Ti}_{2}$ phase layer. A welldefined electron diffraction ring pattern could be formed, as shown in Figure 5(c), from regions where 

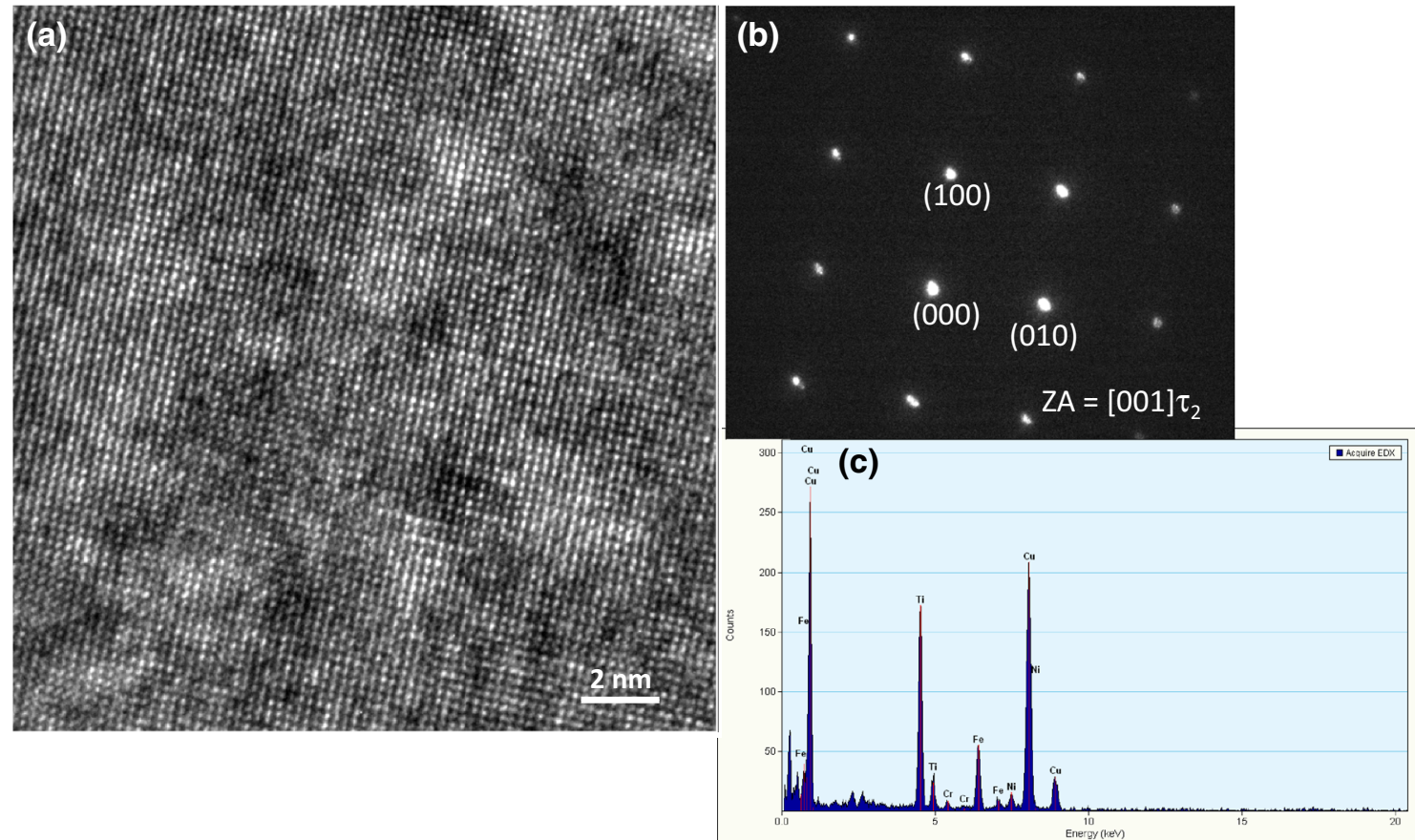

Fig. 3-(a) High-resolution TEM image (b) SADP and (c) EDS spectrum from the $\tau_{2}$ ternary phase marked as 2 in Fig. 1.
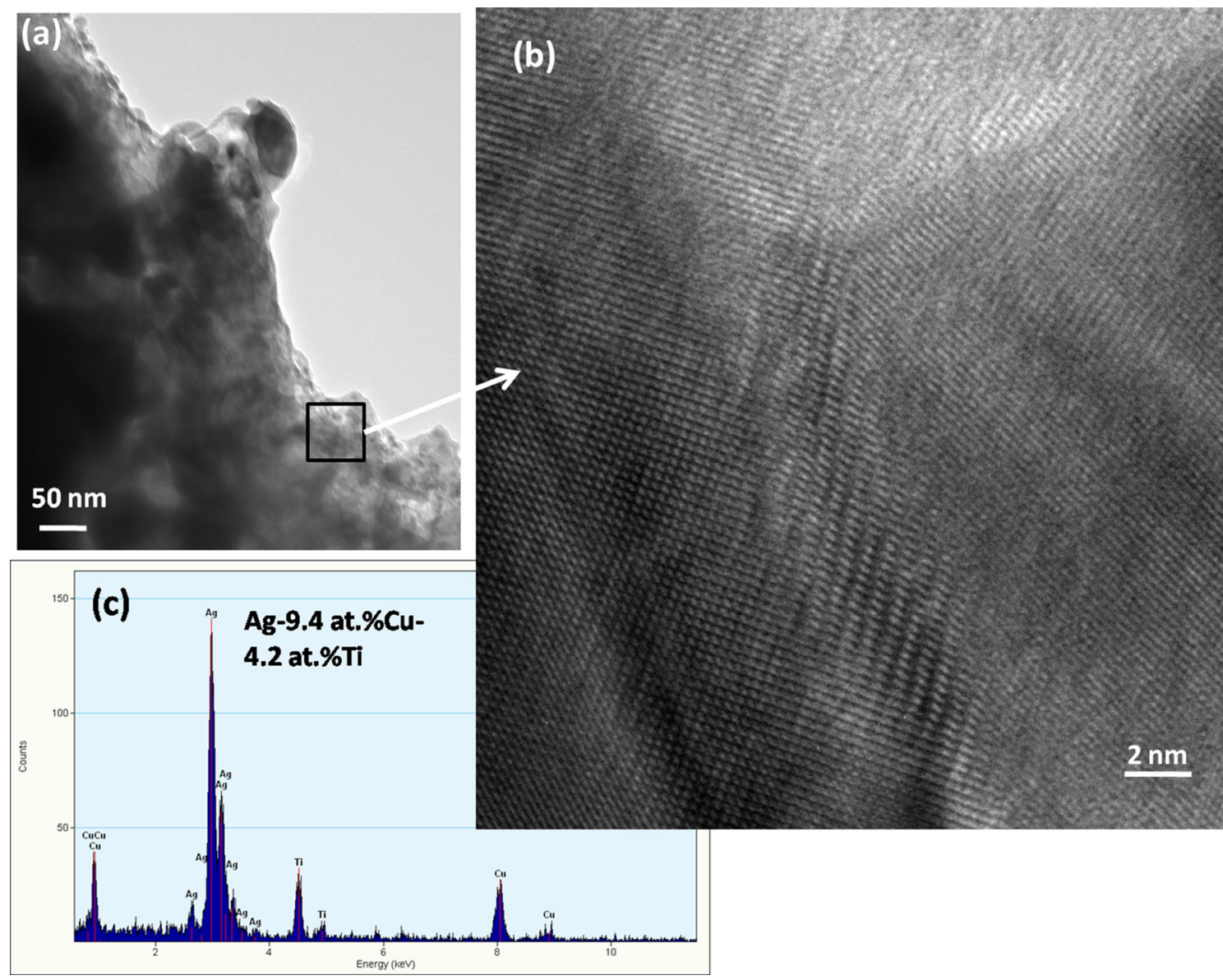

Fig. 4-(a) Bright-field TEM micrograph, (b) high-resolution image, and (c) EDS spectrum from the residual $\mathrm{Ag}(\mathrm{Cu}, \mathrm{Ti})$ phase marked as 3 in Fig. 1. 

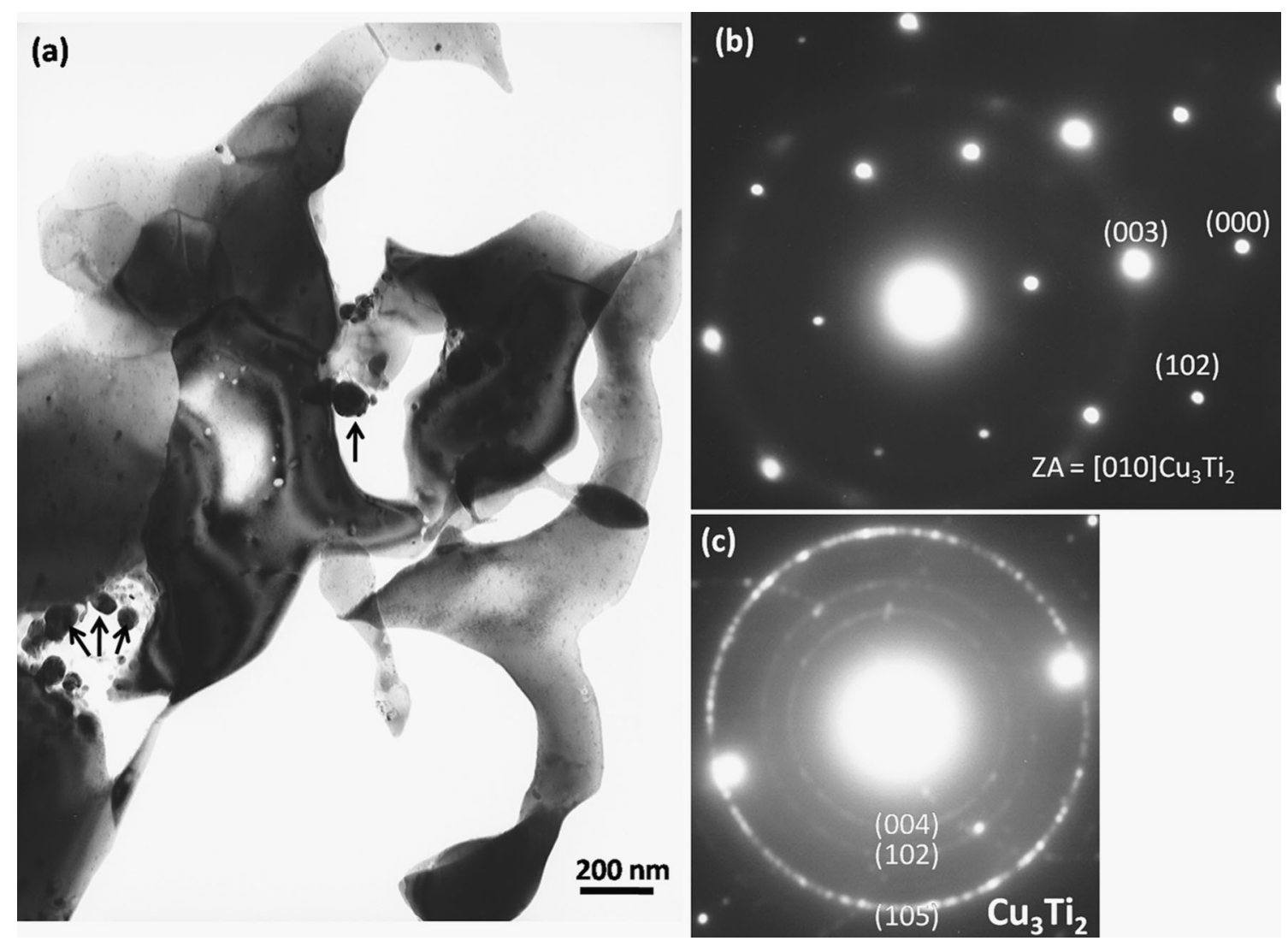

Fig. 5- (a) Bright-field TEM micrograph, (b) SADP, and (c) electron diffraction ring pattern from the $\mathrm{Cu}_{3} \mathrm{Ti}_{2}$ phase formed in the $\mathrm{BZ}$, marked 4 in Fig. 1.

the density of such nanocrystalline grains was sufficiently high. Thus, TEM analysis convincingly provided the evidence for formation of polycrystalline $\mathrm{Cu}_{3} \mathrm{Ti}_{2}$ phase between the $\tau_{2}$ - and the $\mathrm{Cu}_{4} \mathrm{Ti}_{3}$-phase layers in the BZ. It may be further noted that the adjacent coexistence of the $\tau_{2}-$ and $\mathrm{Cu}_{3} \mathrm{Ti}_{2}$-phase in the $\mathrm{BZ}$ can be justified by the fact that the composition of $\tau_{2}$ is in equilibrium with that of the $\mathrm{Cu}_{3} \mathrm{Ti}_{2}$ according to the $\mathrm{Cu}$ Fe-Ti phase diagram. ${ }^{[21,22]}$

During TEM examination, it was observed that at certain locations, an amorphous phase formed in the BZ. Figure 6(a) shows the bright-field TEM image of a region showing the formation of amorphous phase. The corresponding electron diffraction pattern and the EDS spectrum from the amorphous region are shown in Figures 6(b) and (c), respectively. The presence of the amorphous phase was characterized by lack of any crystal structure (Figure 6(a)) and the formation of hallow in SADP (Figure 6(b)). It was also seen that at certain places in the amorphous matrix, a second phase crystallized randomly, defined by the presence of ordered regions. The typical regions showing the possible presence of nuclei of the crystalline second phase are marked by arrows in Figure 6(a). Moreover, at certain locations in the amorphous matrix, clusters of crystalline phases were found to appear. One such typical region is encircled in Figure 6(a). The size of such regions varied in the range 5 to $20 \mathrm{~nm}$. The chemical composition of the amorphous phase, determined by
EDS analysis in TEM, showed predominant presence of $\mathrm{Cu}$ and $\mathrm{Ti}$, with a wide variation in their concentrations, $\mathrm{Cu}_{x} \mathrm{Ti}_{1-x}$, where $0.4<x<0.65$. The presence of minor alloying addition of $\mathrm{Fe}$ and $\mathrm{Ni}$ was also found in the amorphous phase. For example, the composition of the region showed in Figure 6(a) was Ti-36.3 Cu-1.3 Fe (at. pet).

On the Ti-side of the BZ-Ti interface, a two-phase region with almost uniform thickness of about $7 \mu \mathrm{m}$, and average composition of $\mathrm{Ti}-7.4 \mathrm{Cu}-0.9 \mathrm{Ag}$ (at. pct) (marked as 8 in Figure 1) formed due to interdiffusion of $\mathrm{Cu}$ and $\mathrm{Ag}$ into $\mathrm{Ti}$. Within layer 8, a fine lamellar twophase microstructure resembling an eutectoid reaction product formed in colonies. The lamellae measured almost 4 to $5 \mu \mathrm{m}$ in length and the interlamellar spacing was about 600 to $700 \mathrm{~nm}$. The two phases were identified as $\alpha$-Ti matrix and lamellae of $\mathrm{CuTi}_{2}$ intermetallic compound.

\section{B. Variation in Hardness in the Braze Zone}

The variation in the hardness across the $\mathrm{BZ}$ was evaluated using the nano-hardness indentation technique. The hardness $(\mathrm{H})$ at different locations of the $\mathrm{BZ}$ was measured at regular intervals. The elastic modulus (E) of the phases at the indentation locations could also be determined using the load versus depth of penetration curves. Figures 7(a) and (b) show the variation in the nano-hardness and elastic modulus across the BZ, 

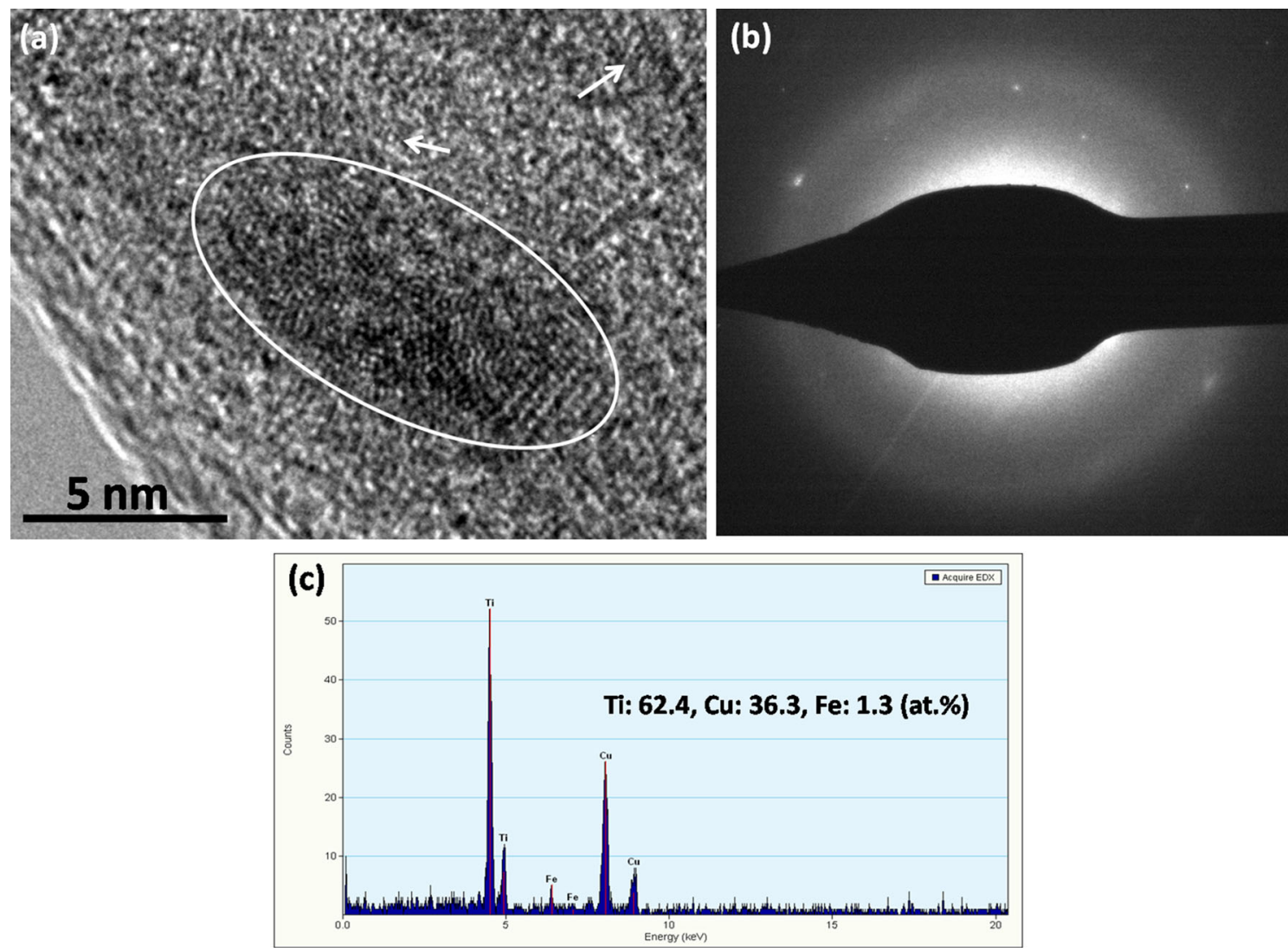

Fig. 6- (a) Bright-field TEM micrograph (b) SADP and (c) EDS spectrum of an amorphous phase formed in the braze zone. The crystallized part is encircled.

respectively. It may be noted that the hardness values rise to about $178 \mathrm{VHN}$ at the location where the $\tau_{2}$ phase formed. Hardness values of as low as 71 VHN within the $\mathrm{BZ}$ could be attributed to the residual unreacted $\mathrm{Ag}(\mathrm{Cu}, \mathrm{Ti})$ phase. Again, high hardness values of about $185 \mathrm{VHN}$ observed were due to the formation of hard intermetallic phases such as $\mathrm{CuTi}, \mathrm{Cu}_{4} \mathrm{Ti}_{3}$, and $\mathrm{Cu}_{3} \mathrm{Ti}_{2}$. The values of $\mathrm{E}$ for the $\mathrm{Ag}(\mathrm{Cu}, \mathrm{Ti})$ phase were about $90 \mathrm{GPa}$ while it increased to about $210 \mathrm{GPa}$ in the $\mathrm{Cu}$-Ti-based intermetallic phases.

\section{Bond Strength and Fracture Behavior of the Brazed Joints}

The tensile bond strength of the brazed SS-Ti joints was found to be $112 \mathrm{MPa}$ with an elongation of 7 pct. The strength of the present joints was better than those reported by Shafiei et al., ${ }^{[20]}$ and comparable to that of steel/Ti joints, brazed using Ag-34Cu-2Ti alloy. ${ }^{[14]}$ Figure 8 shows the BSE image along with the X-ray maps of $\mathrm{Cu}, \mathrm{Ag}, \mathrm{Ti}$, and $\mathrm{Fe}$ of a region on the SS-side of the fractured surface. WDS analysis at location marked 1 and 2 showed high intensity of $\mathrm{Ti}$ and $\mathrm{Cu}$ with some $\mathrm{Fe}$ and $\mathrm{Cr}$. Figure 9 shows BSE image of a region on the Ti-side of the fracture surface, with the X-ray maps of $\mathrm{Cu}, \mathrm{Ag}$, and $\mathrm{Ti}$. The X-ray maps show prominent regions where $\mathrm{Ag}$ is highly concentrated. Most of the regions show the presence of $\mathrm{Cu}$ and $\mathrm{Ti}$. Therefore, the locations marked 1 and 2 in Figure 8 are intermetallics of $\mathrm{Cu}$ and $\mathrm{Ti}$, while the bright phase marked as 3 may be unreacted $\mathrm{Ag}(\mathrm{Cu}, \mathrm{Ti})$ phase. Similarly, on the Ti-side of the fracture surface, the intermetallic compounds of the $\mathrm{Cu}-\mathrm{Ti}$ system and the $\mathrm{Ag}(\mathrm{Cu}, \mathrm{Ti})$ phase were identified.

The XRD plots acquired from the SS- and Ti-sides of the fractured samples are shown in Figures 10(a) and (b), respectively. Apart from the most intense peak of $\gamma$-Fe, formed due to the stainless steel substrate, prominent peaks of the phases $\mathrm{Ag}, \mathrm{CuTi}, \mathrm{Cu}_{4} \mathrm{Ti}_{3}, \mathrm{Cu}_{3} \mathrm{Ti}_{2}$, and $\mathrm{CuTi}_{2}$ were also identified in Figure 10(a). Similarly, distinct peaks of all of these phases along with reflections for Ti were identified in the XRD plot in Figure 10(b). Identification of these phases in the XRD plots of the fractured surfaces corroborated the formation of the $\mathrm{Cu}$ $\mathrm{Ti}$ intermetallic phases, as was postulated using X-ray maps. Therefore, it may be assumed that the fracture of the SS-Ti joints takes place by the propagation of the cracks through a number of intermetallic compounds and not along any particular compound/interface in the BZ.

\section{DISCUSSION}

\section{A. Interfacial Reactions of the Braze Alloy with the Base Materials}

1. Stainless steel-braze alloy interface

As mentioned earlier, due to interaction of the molten $\mathrm{Ag}-28 \mathrm{Cu}$ eutectic braze alloy with $\mathrm{SS}$, a layer of $\mathrm{Ni}$ - 


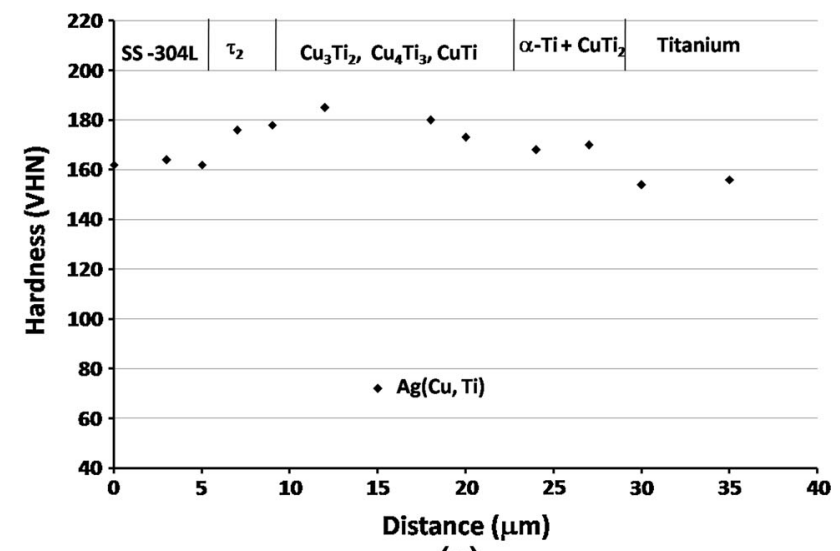

(a)

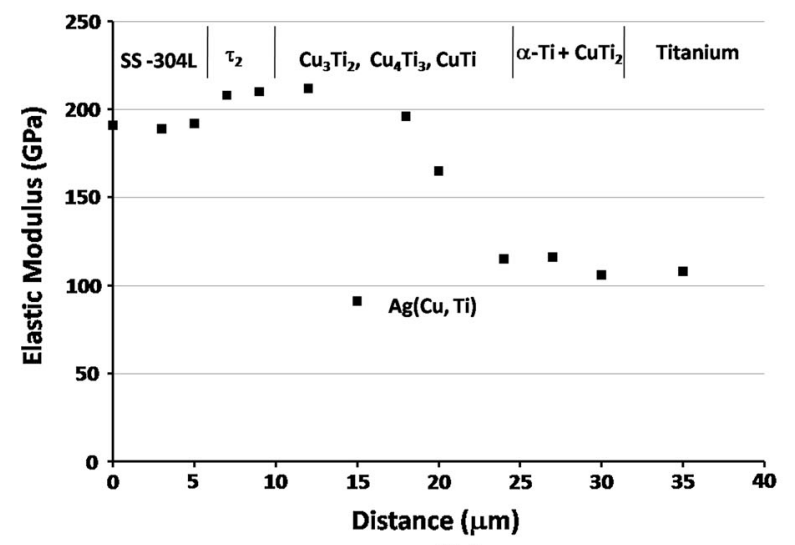

(b)

Fig. 7-Variation in (a) nano-hardness and (b) elastic modulus across the SS-Ti braze zone.

depleted $\alpha-\mathrm{Fe}(\mathrm{Cr}, \mathrm{Ni})$ solid solution formed at the interface (layer 1). The preferential dissolution of $\mathrm{Ni}$ as compared to $\mathrm{Fe}$ in the liquid phase of $\mathrm{Ag}-\mathrm{Cu}$ system may be attributed to the higher solubility of $\mathrm{Ni}$ in the liquid phase. ${ }^{[23,24]}$ Such dissolution of Ni (a $\gamma$-stabilizer) into the braze alloy and hence enrichment of $\mathrm{Cr}$ (an $\alpha$-stabilizer) may have led to a change in the crystal structure to bcc $\alpha$-Fe in the interaction zone. Formation of a layer of $\alpha-\mathrm{Fe}$ on the surface of austenitic stainless steel, due to dissolution of $\mathrm{Ni}$ during interaction with molten metals such as $\mathrm{Pb}-\mathrm{Li}$ alloy ${ }^{[25]}$ and $\mathrm{Pb}$-Bi eutectic alloy ${ }^{[26]}$ was reported earlier.

\section{Braze alloy-titanium interface}

A eutectoid layer 8 , consisting of $\alpha$-Ti and $\mathrm{CuTi}_{2}$ phases, formed at the Ti-braze alloy interface in the process of brazing. Formation of such two-phase regions on the Ti-side is a commonly observed phenomenon during the brazing of $\mathrm{Ti}$ with Ag-based alloys. ${ }^{[10,12,14,16,19]}$ Recently, the formation of $\alpha-\mathrm{Ti}+$ $\mathrm{CuTi}_{2}$ eutectoid due to interfacial reaction of $\mathrm{Ti}$ with $\mathrm{Ag}-28 \mathrm{Cu}$ eutectic alloy at $1123 \mathrm{~K}\left(850{ }^{\circ} \mathrm{C}\right)$ was also confirmed by Shiue et al. using TEM analysis. ${ }^{[19]}$ The present authors showed recently, that the two phases in the $\alpha-\mathrm{Ti}+(\mathrm{Cu}, \mathrm{Ag}) \mathrm{Ti}_{2}$ eutectoid layer, formed during brazing of SS to Ti with an Ag-Cu-based alloy at $1203 \mathrm{~K}$ $\left(930^{\circ} \mathrm{C}\right)$, bear an orientation relationship. ${ }^{[10]}$
In spite of being the major element in the braze alloy, Ag did not diffuse much into the $\mathrm{Ti}$ base material through the BZ/Ti interface, which is also evident from the X-ray maps of $\mathrm{Ti}$ and $\mathrm{Cu}$ in Figure 2. This could be attributed to the fact that $\mathrm{Cu}$ is a faster diffusing species compared to $\mathrm{Ag}$ in $\alpha$-Ti matrix; the activation energies for diffusion being 195 and $205 \mathrm{~kJ} / \mathrm{mol}$, respectively. ${ }^{\text {[27] }}$ In fact, at the temperature of brazing, the diffusion coefficients differed by about three orders of magnitude $\left(D_{\mathrm{Cu}}^{\alpha \mathrm{Ti}}=2.08 \times 10^{-14} \mathrm{~m}^{2} / \mathrm{s}\right.$ and $\left.D_{\mathrm{Ag}}^{\alpha \mathrm{Ti}}=2.60 \times 10^{-17} \mathrm{~m}^{2} / \mathrm{s}\right)$ which is consistent with the observations in this work. Moreover, $\mathrm{Cu}$ being a $\beta$-stabilizer, leads to the formation of a $\beta$-Ti( $\mathrm{Cu}$ ) layer of solid solution at the interface by diffusion of $\mathrm{Cu}$ in $\mathrm{Ti}$. Such formation of $\beta$-solidsolution phase is quite often observed in the diffusion couples of Ti- and $\mathrm{Zr}$-based systems, especially in those which undergo eutectoid transformations; for example, in $\mathrm{Ti}-X$ and $\mathrm{Zr}-X$ systems $(X=\mathrm{Cu}, \mathrm{Ag}, \mathrm{Au}){ }^{\left[{ }^{[28]} \text { It may }\right.}$ be noted that, Laik et al. ${ }^{[29]}$ demonstrated that the $\beta$-Ti $(\mathrm{Cu})$ solid-solution phase is formed by solid state reactive interdiffusion of $\mathrm{Cu}$ and $\mathrm{Ti}$ at temperatures as low as $1053 \mathrm{~K}\left(780{ }^{\circ} \mathrm{C}\right)$, i.e., much below the $\alpha-\beta$ transus. Also, it is known that even during rapid quenching, the $\beta$-phase undergoes eutectoid decomposition in near-eutectoid Ti-Cu alloys. ${ }^{[30,31]}$ Therefore, during the process of cooling from the brazing temperature, the $\beta$-Ti $(\mathrm{Cu})$ solid solution that formed in the region 8 , underwent active eutectoid transformation to the product phases $\alpha-\mathrm{Ti}$ and $\mathrm{CuTi}_{2}$ in the form of lamellar aggregates of phase mixture.

\section{B. Phase Formation in the Braze Zone}

The formation of various phases in the BZ, marked 2 to 7 in Figure 1, is essentially due to interdiffusion of various elements present in the BZ, during brazing (in liquid state), and subsequent cooling to room temperature (in solid state). The layer marked 2 in Figure 1, formed on the SS-side of the BZ, primarily consisted of $\mathrm{Cu}$, Ti and $\mathrm{Fe}$ (Table II). It may be noted that five ternary compounds, viz., $\tau_{i}(i=1$ to 5$)$ have been reported in the $\mathrm{Cu}-\mathrm{Fe}-\mathrm{Ti}$ system, ${ }^{[21,32]}$ where $\tau_{1}, \tau_{2}$ and $\tau_{3}$ are based on the binary $\mathrm{Cu}-\mathrm{Ti}$ phases $\mathrm{Cu}_{2} \mathrm{Ti}, \mathrm{Cu}_{3} \mathrm{Ti}_{2}$ and $\mathrm{Cu}_{4} \mathrm{Ti}_{3}$, respectively. The results of recent investigations on the $\mathrm{Cu}-\mathrm{Fe}-\mathrm{Ti}$ system by $\mathrm{Bo}$ et al. ${ }^{[22]}$ are in good agreement with those of van Beek et al. ${ }^{[32]}$ with respect to these ternary compounds $\left(\tau_{i}\right)$. The composition of the $\tau_{2}$ phase, reported by Bo et al. ${ }^{[2]}$ in equilibrated alloys, matched closely with that of layer 2 in the present study. X-ray diffraction studies revealed that the structure of $\tau_{2}$ phase is close to that of $\mathrm{Cu}_{3} \mathrm{Ti}_{2} \cdot{ }^{[32]}$ The SADP in Figure 3(b) could also be indexed in terms of the $\mathrm{Cu}_{3} \mathrm{Ti}_{2}$ type tetragonal structure with $\mathrm{P} 4 / \mathrm{nmm}$ space group. Therefore, the layer 2 was identified as ternary intermetallic compound $\tau_{2}$, containing substantial amount of $\mathrm{Fe}$. The formation of a layer of intermetallic compound with high amount of $\mathrm{Fe}$, on the steel side of the BZ, during the brazing of steel to Ti using Ag-Cu-based alloys, was also reported by other workers. ${ }^{[3,20]}$ While Elrefaey and Tillmann ${ }^{[13]}$ reported the formation of FeTi phase at $1203 \mathrm{~K}(930$ $\left.{ }^{\circ} \mathrm{C}\right)$, Shafiei et al. ${ }^{[20]}$ showed the formation of $\mathrm{CuTi}$ 

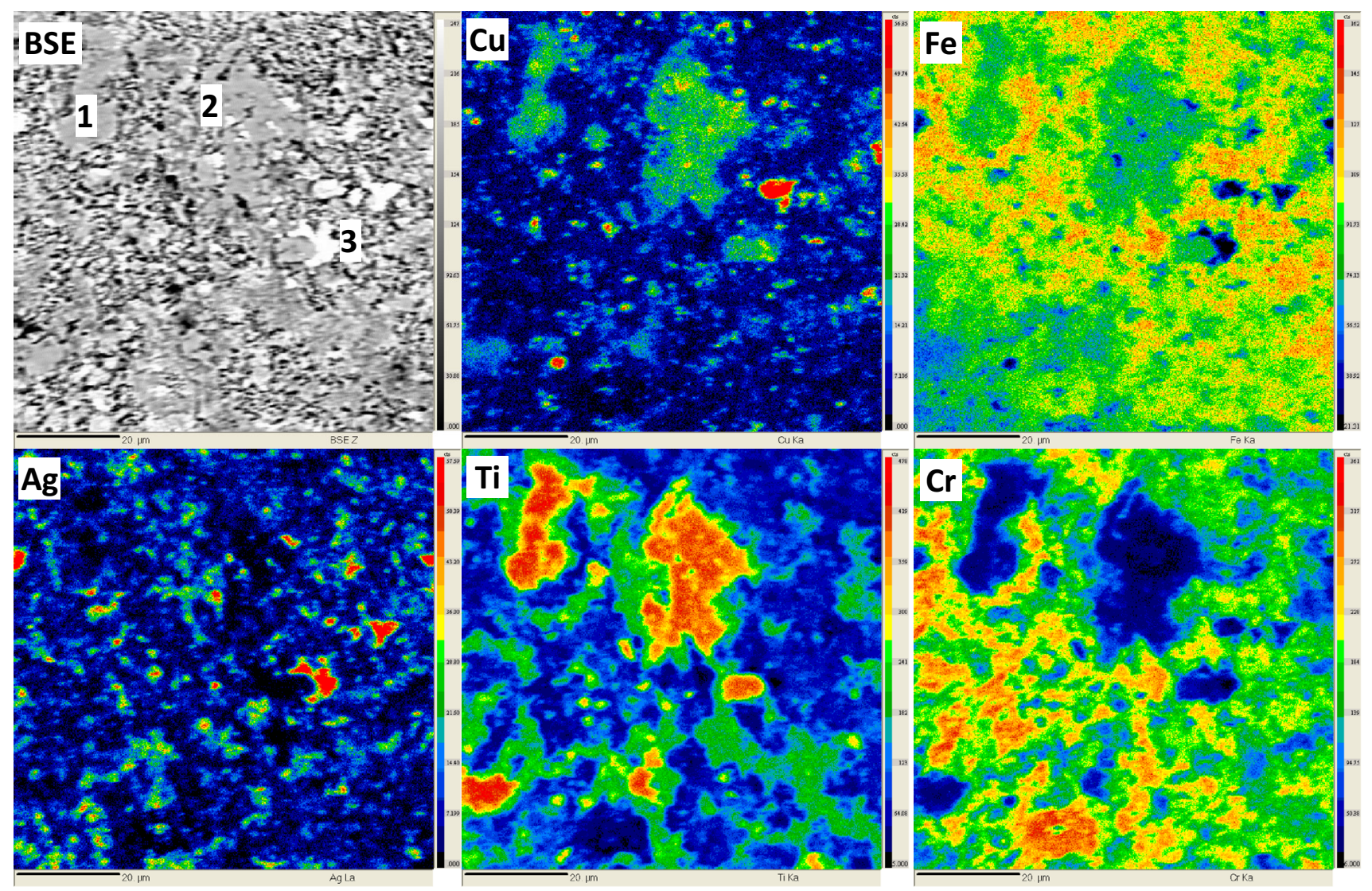

Fig. 8-Elemental X-ray mapping of $\mathrm{Cu}, \mathrm{Fe}, \mathrm{Ag}$, Ti, and $\mathrm{Cr}$ along with the corresponding BSE image of a region on the SS-side of the fracture surface of a SS-Ti braze joint.

phase with about 14 wt pct of Fe. However, neither of these studies reported the crystal structures of these respective phases. Interestingly, the composition of the layer reported by Shafiei et al ${ }^{[20]}$ is within the reported limits of that of $\tau_{2},{ }^{[22,32]}$ with higher amount of $\mathrm{Fe}$ than in the present case. Moreover, the $\mathrm{Cu}-\mathrm{Fe}-\mathrm{Ti}$ phase diagram shows that the solubility of $\mathrm{Fe}$ in $\mathrm{CuTi}$ is quite negligible. ${ }^{[22,32]}$ Hence, the possibility of this phase being CuTi phase was ruled out. The $\tau_{2}$ phase also contained a significant amount of $\mathrm{Ni}(\sim 3.4$ at. pct). The source of this $\mathrm{Ni}$ was attributed to preferential dissolution of $\mathrm{Ni}$ from the SS base material during brazing. The Ni that dissolved into the braze melt, almost entirely entered into the $\tau_{2}$ phase layer during its formation.

The residual $\operatorname{Ag}(\mathrm{Cu}, \mathrm{Ti})$ solid-solution phase, formed as islands in the BZ (layer 3), contained about 4.2 at. pct $\mathrm{Ti}$. The presence of $\mathrm{Ti}$ in this phase reconfirms the dissolution of Ti at the braze alloy/Ti interface. The $\mathrm{Cu}$ and $\mathrm{Ti}$ contents of the $\mathrm{Ag}(\mathrm{Cu}, \mathrm{Ti})$ phase almost matched with the concentration in equilibrium with $\mathrm{Cu}_{3} \mathrm{Ti}_{2}$ and $\mathrm{Cu}_{4} \mathrm{Ti}_{3}$ at $973 \mathrm{~K}\left(700{ }^{\circ} \mathrm{C}\right) \cdot{ }^{[33]}$ Hence, almost the entire $\mathrm{Cu}$ in the braze alloy was utilized in the interfacial reactions to form the different phases in the $\mathrm{BZ}$, and the residual amount remained in equilibrium with the adjacent phases.

Among the $\mathrm{Cu}$-Ti-based binary intermetallic layers in the BZ, CuTi (layer 6, Figure 1) has the highest melting point and can be assumed to be the first phase to form.
The formation of $\mathrm{CuTi}$ in the $\mathrm{BZ}$ during the brazing of steels to Ti using Ag-Cu-based alloys has been reported irrespective of the brazing conditions. ${ }^{[12,13,20,34,35]}$ This phase also formed in the interaction zone during the solid-liquid reaction between $\mathrm{Ti}$ and $\mathrm{Ag}-\mathrm{Cu}$ alloys ${ }^{[1,36]}$ and solid-solid reactive diffusion between $\mathrm{Ti}$ and $\mathrm{Cu} .{ }^{[29]}$ Laik et al. ${ }^{[29]}$ demonstrated that during the reactive diffusion of $\mathrm{Cu}$ and $\mathrm{Ti}, \mathrm{CuTi}$ is the first one to form in the diffusion zone, using the "effective heat of formation model." ${ }^{[37,38]}$ Also, Liotard et al. ${ }^{[39]}$ revealed that the first phase to form at the $\mathrm{Cu} / \mathrm{Ti}$ interface is $\mathrm{CuTi}$, in thin-film experiments. The formation of the $\mathrm{Cu}_{4} \mathrm{Ti}_{3}$ phase (layer 5) in the SS/Ti BZ was also reported in other investigations. ${ }^{[12,13,20,34-36]}$ However, contrary to the present observations, Shiue et al. ${ }^{[19]}$ and Shafiei et al. ${ }^{20]}$ reported the formation of the $\mathrm{Cu}_{4} \mathrm{Ti}$ phase in the $\mathrm{BZ}$, whereas they did not report the formation of $\mathrm{Cu}_{3} \mathrm{Ti}_{2}$ phase which formed conspicuously in the present study. Andrieux et al. ${ }^{[40]}$ in an experimental investigation on the phase stability study on the $\mathrm{Cu}-\mathrm{Ti}$ system showed that the $\mathrm{Cu}_{3} \mathrm{Ti}_{2}$ phase is stable and can form by solid state reaction in a temperature range of $1063 \mathrm{~K}$ to 1133 $\mathrm{K}\left(790{ }^{\circ} \mathrm{C}\right.$ to $\left.860{ }^{\circ} \mathrm{C}\right)$.

The presence of $\mathrm{Cu}$-Ti-based amorphous phase in the BZ, as shown earlier, signifies that the entire melt did not transform into crystalline phases upon solidification. The $\mathrm{Cu}$-Ti system is known to form metallic glass and extensive work on the crystallization behavior of the 

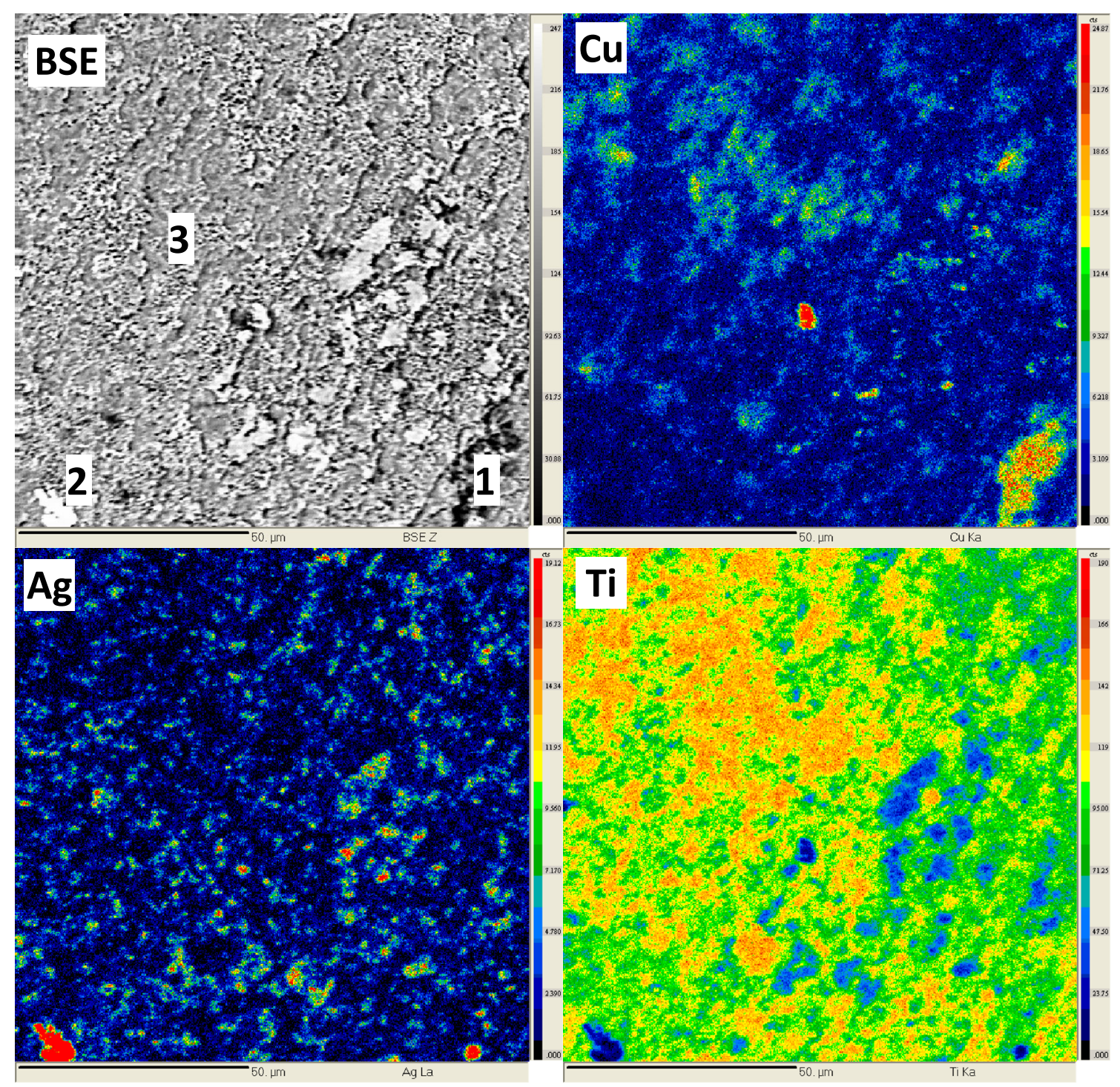

Fig. 9-Elemental X-ray mapping of $\mathrm{Cu}, \mathrm{Ag}$, and $\mathrm{Ti}$ along with the corresponding BSE image of a region on the Ti-side of the fracture surface of a SS-Ti braze joint.

amorphous phases of this system has been reported in the literature. ${ }^{[41-50]}$ It may be noted that in the present case, the brazing experiments were carried out using induction heating with a relatively high rate of about $1.667 \mathrm{~K} / \mathrm{s}\left(100^{\circ} \mathrm{C} / \mathrm{min}\right)$. The rate of cooling in this case was also very high owing to the fact that only the joining specimens, and not the entire chamber, were heated during brazing. The presence of the amorphous phase in the BZ may be attributed to fast cooling of the SS/Ti joined pieces after the brazing operation.

The glass-forming ability of alloys in the $\mathrm{Cu}$-Ti system has been a topic of research since decades and hence was investigated extensively. ${ }^{[41-50]}$ Formation of amorphous phase in a wide range of compositions around $\mathrm{Cu}_{50} \mathrm{Ti}_{50}$ has been demonstrated using rapid solidification, ${ }^{[4-47]}$ pulsed laser quenching, ${ }^{[43]}$ and mechanical alloying. ${ }^{[48]}$ The kinetics of crystallization of these alloys were found to be sluggish, and the activation energy for crystallization $(Q)$ was reported to vary between 71.4 and $126 \mathrm{~kJ} /$ mol in the composition range $\mathrm{Cu}_{x} \mathrm{Ti}_{1-x}$, where $0.35<x<$ 0.65 with a maximum at $x=0.55 .^{[42]}$ Hwang et al. ${ }^{[41]}$ showed that the value of $Q$ was maximum for $x=0.35$. Also, it was observed by Delogu and Cocco ${ }^{[48]}$ that the rate of amorphization using powders by mechanical alloying was the highest at the composition $x=0.4$. The studies of Buschow ${ }^{[44,45]}$ showed the formation of amorphous phase in a wide range of composition, $0.28<x<$ 0.76 . He reported the kinetics of transformation and showed that the values of $Q$ attain a maximum at composition $x=0.65{ }^{[44]}$ During the process of solidification, the crystallization of the tetragonal phases $\mathrm{CuTi}_{2}$ (C11b type) and $\gamma$-CuTi (B11 type) is known to compete with the process of amorphization. ${ }^{[43,45,50]}$ The tendency of crystallization of the amorphous phase formed in the $\mathrm{BZ}$ of the present SS/Ti joints was illustrated quite distinctly using TEM analysis. It may be assumed therefore that the crystallites formed in the amorphous phase are either of $\mathrm{CuTi}_{2}$ or CuTi phase. 


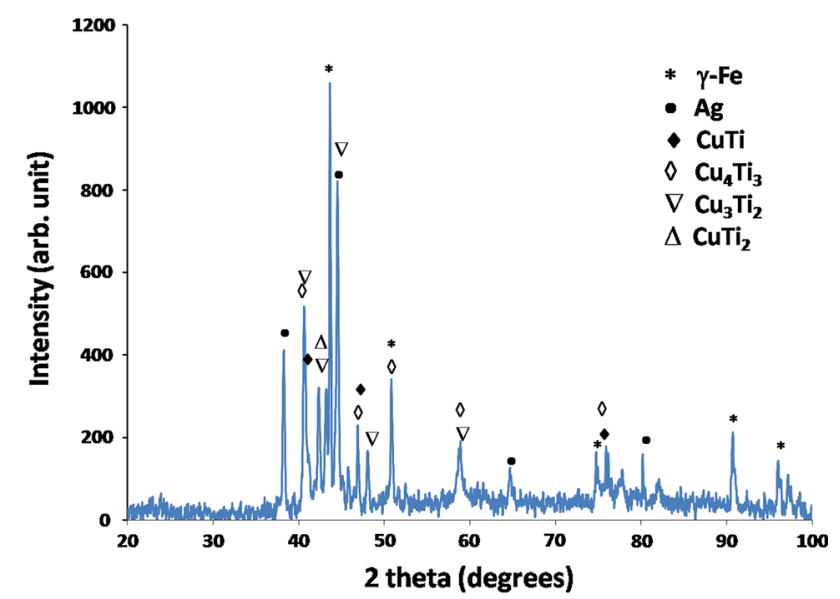

(a)

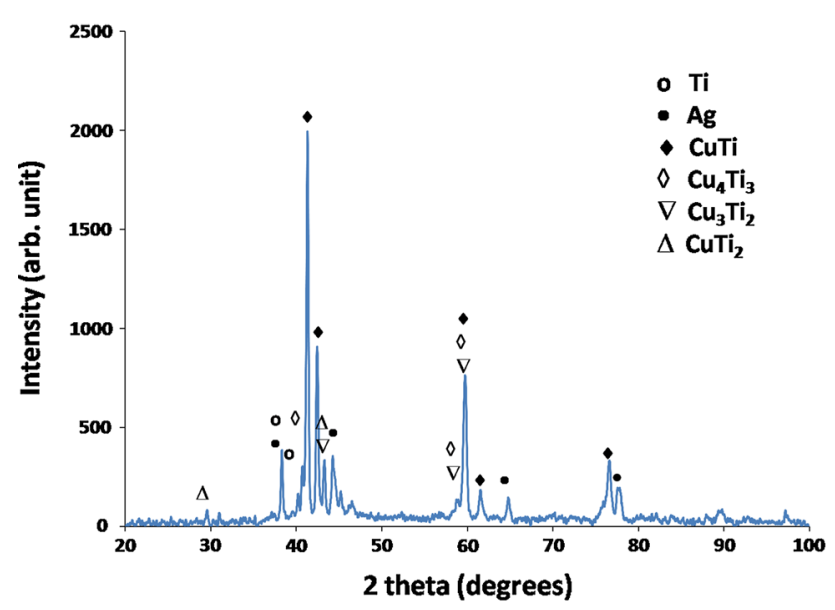

(b)

Fig. 10-X-ray diffraction plot acquired from the of the fractured surfaces of a SS-Ti brazed joint: (a) SS-side and (b) Ti-side.

\section{Microstructural Evolution and Reaction Scheme}

The evolution of the microstructure in the BZ over time during the process of brazing can be presented schematically as shown in Figure 11. Figure 11a shows the initial configuration of the braze assembly. After melting, the Ag-28Cu braze alloy underwent chemical interactions with SS and Ti at the solid-liquid interfaces on the either side, which led to the formation of a $\mathrm{Ni}$ depleted $\alpha-\mathrm{Fe}(\mathrm{Cr}, \mathrm{Ni})$ solid solution (layer1) and a ternary phase $\tau_{2}$ (layer 2 ) at the SS/BZ interface, and $\beta$-Ti(Cu) solid solution (layer 8) and CuTi phase (layer $6)$ at the $\mathrm{BZ} / \mathrm{Ti}$ interface. This intermediate stage is represented in Figure 11(b). The final configuration of the different phases after cooling down to room temperature is shown in Figure 11(c).

The dissolution of $\mathrm{Ti}$ into the braze melt results in the formation of two immiscible liquids, one rich in $\mathrm{Ag}\left(\mathrm{L}_{1}\right)$ and the other rich in $\mathrm{Cu}$ and $\mathrm{Ti}\left(\mathrm{L}_{2}\right)$ due to the presence of a huge miscibility gap in the $\mathrm{Ag}-\mathrm{Cu}-\mathrm{Ti}$ phase diagram. ${ }^{[51]}$ Although the Ag-rich melt $\mathrm{L}_{1}$ has negligible effect on the interfacial reactions, the $\mathrm{Cu}$-Ti-rich melt $\mathrm{L}_{2}$ influences these reactions to a large extent. ${ }^{[19]}$ Subsequent to the formation of the congruent melting $\mathrm{CuTi}$
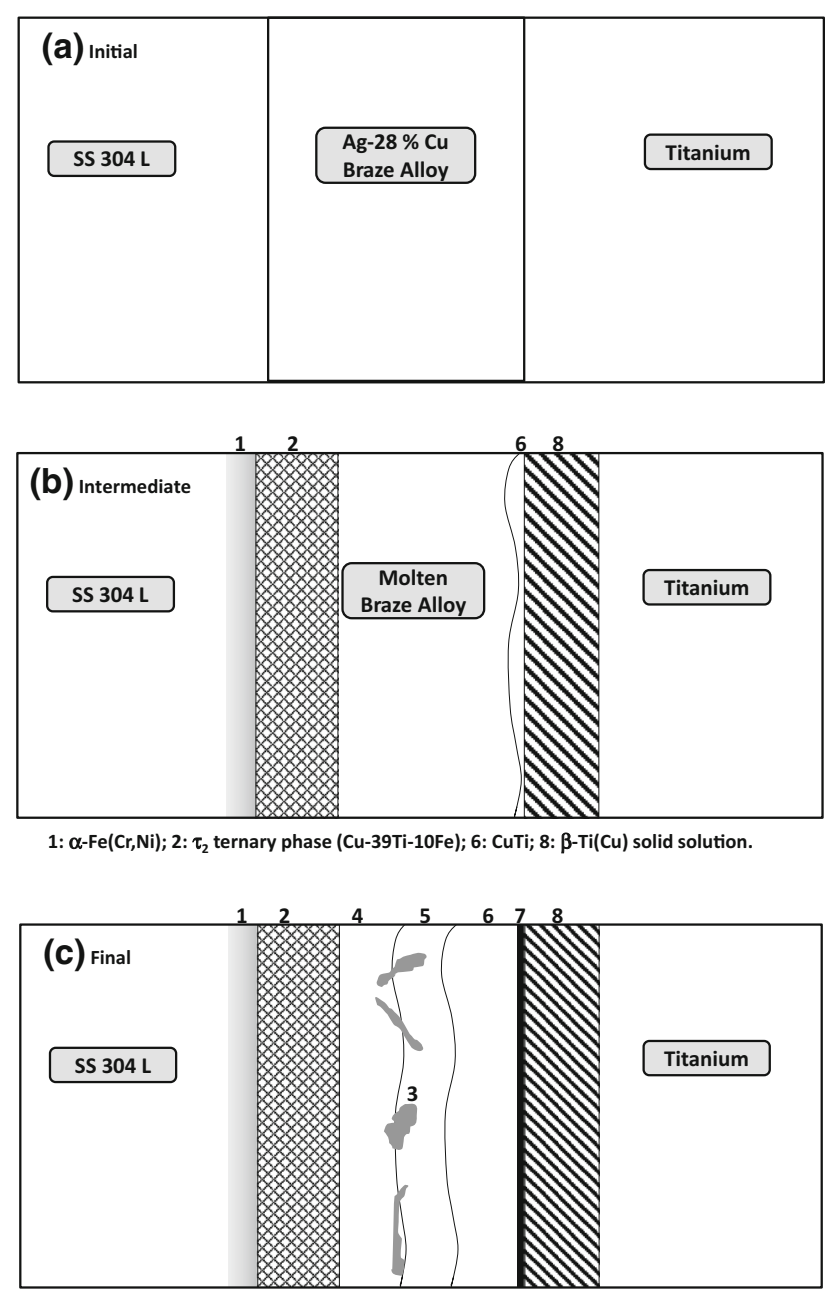

1: $\alpha-\mathrm{Fe}(\mathrm{Cr}, \mathrm{Ni}) ; 2: \tau_{2} ; 3: \mathrm{Ag}(\mathrm{Cu}, \mathrm{Ti}) ; 4: \mathrm{Cu}_{3} \mathrm{Ti}_{2} ; 5: \mathrm{Cu}_{4} \mathrm{Ti}_{3} ; 6: \mathrm{CuTi} ; 7: \mathrm{CuTi}_{2} ; 8: \alpha-\mathrm{Ti}+\mathrm{CuTi}_{2}$.

Fig. 11-Schematic diagrams showing the evolution of the microstructure through $(a)$ initial, $(b)$ intermediate, and $(c)$ final stages of brazing (Not to scale).

phase, $\mathrm{Cu}_{4} \mathrm{Ti}_{3}$ can form through the following peritectoid reaction. ${ }^{[52]}$

$$
\mathrm{L}+\mathrm{CuTi}=\mathrm{Cu}_{4} \mathrm{Ti}_{3}
$$

Subsequently, the interfacial $\mathrm{Cu}_{4} \mathrm{Ti}_{3}$ phase reacts with the molten braze alloy leading to the formation of $\mathrm{Cu}_{3} \mathrm{Ti}_{2}$ phase layer, along with the Ag-rich $\mathrm{Ag}(\mathrm{Cu}, \mathrm{Ti})$ phase, by the following invariant reaction ${ }^{[51]}$ :

$$
U_{5}: \mathrm{L}+\mathrm{Cu}_{4} \mathrm{Ti}_{3}=(\mathrm{Ag})+\mathrm{Cu}_{3} \mathrm{Ti}_{2}
$$

The association of the islands of the $\mathrm{Ag}(\mathrm{Cu}, \mathrm{Ti})$ phase with the $\mathrm{Cu}_{4} \mathrm{Ti}_{3}$ and $\mathrm{Cu}_{3} \mathrm{Ti}_{2}$ phase layers in the microstructure of the BZ (Figure 1) can thus be rationalized. Occurrence of such invariant reactions in the $\mathrm{BZ}$, during brazing of $\mathrm{Cu}$ and $\mathrm{Ti}$ using $\mathrm{Ag}-28 \mathrm{Cu}$, has also been reported. ${ }^{[3]}$

The formation of a narrow $\mathrm{CuTi}_{2}$ phase layer during brazing in similar systems has been demonstrated in a number of earlier studies. ${ }^{[12,13,19,20,36]}$ The formation of the $\mathrm{CuTi}_{2}$ phase between CuTi and Ti can be considered 


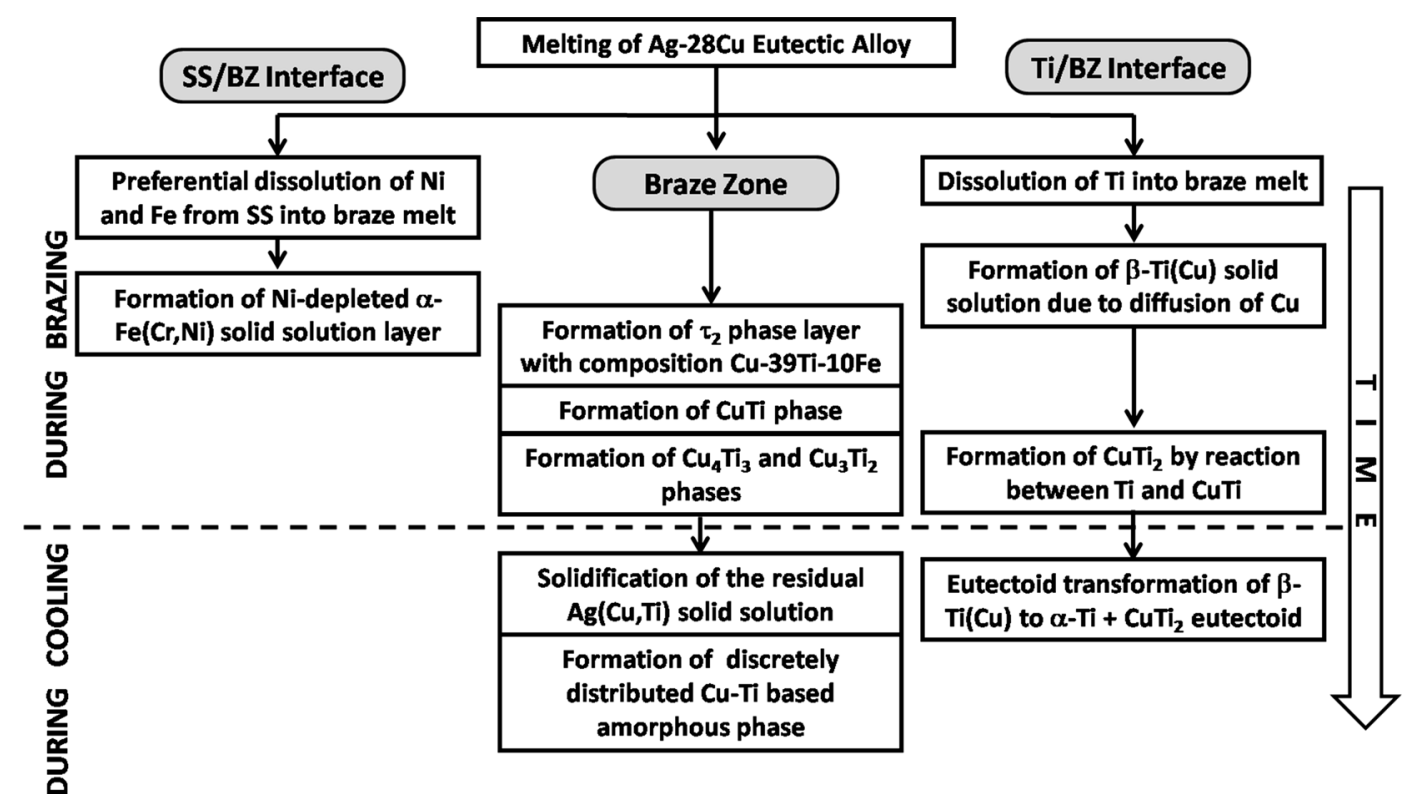

Fig. 12-Schematic representation of the chronological sequence of reactions occurring at the interfaces and the braze zone during the entire brazing cycle.

to be a solid state reaction between these two adjacent phases, caused by interdiffusion of $\mathrm{Cu}$ and $\mathrm{Ti}$ atoms.

The different reactions involved during the entire brazing process may be categorized as those occurring during brazing and those occurring during the subsequent cooling of the brazed joints. Figure 12 presents a schematic diagram delineating these processes.

\section{CONCLUSIONS}

Microstructural evolution and interfacial reactions during vacuum brazing of grade- 2 Ti to SS $304 \mathrm{~L}$, with $\mathrm{Ag}-28 \mathrm{Cu}$ eutectic alloy foils at $1108 \mathrm{~K}\left(835^{\circ} \mathrm{C}\right)$, were investigated in the present study. Adequate wetting of the braze alloy, leading to good quality bond with tensile strength of $112 \mathrm{MPa}$ was observed. At the SS/ braze alloy interface of the $\mathrm{BZ}$ a $2-\mu \mathrm{m}$ thick Ni-depleted layer of $\alpha-\mathrm{Fe}(\mathrm{Cr}, \mathrm{Ni})$ solid solution formed due to preferential dissolution of $\mathrm{Ni}$ by solid-liquid interaction, while diffusion of $\mathrm{Cu}$ into $\mathrm{Ti}$ substrate stabilized a $7-\mu \mathrm{m}$ thick layer of $\beta$ - Ti $(\mathrm{Cu})$ solid solution which subsequently decomposed to a $\alpha-\mathrm{Ti}+\mathrm{CuTi}_{2}$ eutectoid mixture, with interlamellar spacing of 600 to $700 \mathrm{~nm}$. In the $\mathrm{BZ}$, a $\mathrm{Cu}-\mathrm{Ti}-\mathrm{Fe}$-based ternary compound $\tau_{2}$, and four binary $\mathrm{Cu}-\mathrm{Ti}$ intermetallic phases viz., $\mathrm{Cu}_{3} \mathrm{Ti}_{2}$, $\mathrm{Cu}_{4} \mathrm{Ti}_{3}, \mathrm{CuTi}$ and $\mathrm{CuTi}_{2}$ formed by dissolution and diffusion of $\mathrm{Ti}$ from the substrate. The sequence of formation of these compounds was $\tau_{2}$ and $\mathrm{CuTi}$, followed by $\mathrm{Cu}_{3} \mathrm{Ti}_{2}$ and $\mathrm{Cu}_{4} \mathrm{Ti}_{3}$, and finally $\mathrm{CuTi}_{2}$. The unreacted $\mathrm{Ag}$ was the last phase to solidify and contained 9.4 at. pct $\mathrm{Cu}$ and 4.2 at. pct Ti. The presence of a $\mathrm{Cu}$-Ti-based amorphous phase with varied composition could be identified in the BZ which showed tendency of crystallization. The fractured surfaces of the $\mathrm{SS} / \mathrm{Ti}$ joints showed that the crack propagated through a number of intermetallic phases, rather than though the braze-metal interfaces, prior to failure.

\section{ACKNOWLEDGMENTS}

The work is a part of the India-UK collaborative research program JOINT. One of the authors (AAS) is grateful to the UK's Engineering and Physical Sciences Research Council (EPSRC) for the financial support. The authors are thankful to Dr. R. N. Singh, Dr. B. C. Maji and Dr. T. S. R. Ch. Murthy of BARC, and Mrs. B. A. Chalke of TIFR for their cooperation and extending the experimental facilities.

\section{REFERENCES}

1. A. Shapiro and A. Rabinkin: Weld. J., 2003, vol. 83, pp. 36-43.

2. S. Kundu, M. Ghosh, A. Laik, K. Bhanumurthy, G.B. Kale, and S. Chatterjee: Mater. Sci. Eng. A, 2005, vol. 407, pp. 36-43.

3. M.M. Cheepu, V. Muthupandi, and S. Loganathan: Mater. Sci. Forum, 2012, vol. 710, pp. 620-25.

4. A. Fiji, T.H. North, K. Ameyama, and M. Futamata: Mater. Sci. Technol., 1992, vol. 8, pp. 219-35.

5. U.K. Mudali, B.M.A. Rao, K. Shanmugam, R. Natarajan, and B. Raj: J. Nucl. Mater., 2003, vol. 321, pp. 40-48.

6. B. Raj and U.K. Mudali: Prog. Nucl. Energy, 2006, vol. 48, pp. 283-313.

7. M.M. Schwartz: Brazing, ASM International, Materials Park, $\mathrm{OH}, 2003$.

8. M.M. Schwartz: Ceramic Joining, ASM International, Materials Park, OH, 1990

9. G. Humpston and D.M. Jacobson: Principles of Soldering and Brazing, ASM International, Materials Park, OH, 1993.

10. A. Laik, A.A. Shirzadi, R. Tewari, A. Kumar, T. Jayakumar, and G.K. Dey: Metall. Mater. Trans A, 2013, vol. 44A, pp. 2212-15.

11. J.G. Lee, S.J. Hong, M. Lee, and C. Rhee: Scripta Mater., 2009, vol. 395 , pp. 145-49. 
12. X. Yue, P. He, J.C. Zhang, and F.Q. Zhu: Mater Charact., 2008, vol. 59, pp. 1721-27.

13. A. Elrefaey and W. Tillmann: Metall. Mater. Trans. A, 2007, vol. 38A, pp. 2956-62.

14. A. Elrefaey and W. Tillmann: J. Mater. Sci., 2007, vol. 42, pp. $9553-58$.

15. A. Elrefaey and W. Tillmann: J. Alloys Compd., 2009, vol. 487, pp. $639-45$

16. A. Elrefaey and W. Tillmann: J. Mater. Sci., 2010, vol. 45, pp. $4332-38$.

17. J.G. Lee, J.K. Lee, S.M. Hong, M.K. Lee, and C.K. Rhee: $J$. Mater. Sci., 2010, vol. 45, pp. 6837-40.

18. M.K. Lee, J.G. Lee, Y.H. Choi, D.W. Kim, C.K. Rhee, Y.B. Lee, and S.J. Hong: Mater. Lett., 2010, vol. 64, pp. 1105-08.

19. R.K. Shiue, S.K. Wu, F.Y. Chen, and T.E. Yang: Metall. Mater. Trans A, 2012, vol. 43A, pp. 1742-46.

20. A. Shafiei, P. Abachi, K. Dehghani, and K. Pourazarang: Mater. Manuf. Proc., 2010, vol. 25, pp. 1333-40.

21. V. Raghavan: J. Phase Equilib., 2002, vol. 23, pp. 172-74.

22. H. Bo, L.I. Duarte, W.J. Zhu, L.B. Liu, H.S. Liu, Z.P. Jin, and C. Leinenbach: CALPHAD, 2013, vol. 40, pp. 24-33.

23. O. Kubaschewski: in Ternary Alloys: A comprehensive Compendium of Evaluated Constitutional Data and Phase Diagrams, G. Petzow, G. Effenberg, eds., Wiley, Weinheim, 1988, vol. 1, pp. 557-62.

24. O. Kubaschewski: in Ternary Alloys: A Comprehensive Compendium of Evaluated Constitutional Data and Phase Diagrams, G. Petzow, G. Effenberg, eds., Wiley, Weinheim, 1988, vol. 1, pp. 596-604.

25. H. Tas, P. Lemaitre, J. Dekeyser, W. Vandermeulen, and F.D. Schutter: Fusion Eng. Des., 1991, vol. 14, pp. 321-28.

26. A. Aiello, M. Azzati, G. Benamati, A. Gessi, B. Long, and G. Scaddozzo: J. Nucl. Mater., 2004, vol. 335, pp. 169-73.

27. O. Taguchi and Y. Iijima: Philos. Mag. A, 1995, vol. 72, pp. 1649 55.

28. G.P. Tiwari, O. Taguchi, Y. Iijima, and G.B. Kale: Defect Diffus. Data Pt. A, 2008, vol. 279, pp. 117-24.

29. A. Laik, K. Bhanumurthy, G.B. Kale, and B.P. Kashyap: Intl. J. Mater. Res., 2012, vol. 103, pp. 661-72.

30. F.C. Holden, A.A. Watts, H.R. Ogden, and R.I. Jaffee: Trans. AIME, 1955, vol. 203, pp. 117-25.

31. T.A. Bhaskaran, R.V. Krishnan, and S. Ranganathan: Metall. Mater. Trans. A, 1995, vol. 26A, pp. 1367-77.
32. J.A. van Beek, A.A. Kodentsov, and F.J.J. van Loo: J. Alloys Compds., 1995, vol. 217, pp. 97-103.

33. O. Kubaschewski: Landolt-Bornstein New Series, Springer, Berlin, 2005, vol. IV/11C3, pp. 63-74.

34. C.C. Liu, C.L. Ou, and R.K. Shiue: J. Mater. Sci., 2002, vol. 37, pp. $2225-35$.

35. J.G. Lee, S.J. Hong, M.K. Lee, and C.K. Rhee: J. Nucl. Mater., 2009, vol. 395 , pp. $145-49$.

36. J. Andrieux, O. Dezellus, F. Bosselet, and J.C. Viala: J. Phase Equilib. Diff., 2009, vol. 30, pp. 40-45.

37. R. Pretorious: MRS Proc., 1991, vol. 25, p. 15.

38. R. Pretorious, R. de Reus, and C.C. Theron: Mater. Sci. Eng. R, 1991, vol. 10, p. 1.

39. J.L. Liotard, D. Gupta, P.A. Psaras, and P.S. Ho: J. Apppl. Phys., 1985 , vol. 57 , p. 1895

40. J. Andrieux, O. Dezellus, F. Bosselet, M. Sacerdote-Peronnet, C. Sigala, R. Chiriac, and J.C. Viala: J. Phase Equilib. Diffus., 2008, vol. 29 , pp. 156-62.

41. C.H. Hwang, S. Kang, and K. Cho: Scripta Metall., 1985, vol. 19, pp. $1403-08$.

42. C.H. Hwang, Y.J. Ryeom, and K. Cho: J. Less Common Metals, 1982, vol. 86, pp. 187-94.

43. C.G. Woychik, D.H. Lowndes, and T.B. Massalski: Acta Metall., 1985, vol. 33, pp. 1861-71.

44. K.H.J. Buschow: Scripta Metall., 1983, vol. 17, pp. 1135-39.

45. K.H.J. Buschow: Acta Metall., 1983, vol. 31, pp. 155-60.

46. A. Pratap, K.N. Lad, T.L. Shanker Rao, P. Majumdar, and N.S. Saxena: J. Non-Cryst. Solids, 2004, vols. 345-346, pp. 178-81.

47. A. Pratap, T.L. Shanker Rao, K.N. Lad, and H.D. Dhurandhar: J. Non-Cryst. Solids, 2007, vol. 353, pp. 2346-49.

48. F. Delogu and G. Cocco: J. Alloys Compd., 2003, vol. 352, pp. 92 98.

49. C. Colinet, A. Pasturel, and K.H.J. Buschow: J. Alloys Compd., 1997, vol. 247, pp. 15-19.

50. Z. Hen, Z. Bangwei, T. Zhaosheng, and W. Lijun: Metall. Trans. A, 1992, vol. 23A, pp. 1627-30.

51. P. Villars, A. Prince, and H. Okamoto: Handbook of Ternary Alloy Phase Diagrams, ASM International, Materials Park, OH, 1995.

52. H. Okamoto: J. Phase Equilib., 2002, vol. 26, pp. 549-50.

53. R.K. Shiue, S.K. Wu, and C.H. Chen: J. Alloys Compd., 2004, vol. 372 , pp. $148-57$. 